investigation. This would make clinical medicine more actively productive, and woald provicle a cliass of scientific clinicians from which professcrs of medicine could in the future be selected. Such assistants would be of the rank of, or: actually be, registrars or junior assistant physicians and assistant surgeons, but would; while holding this post, be debarred from private practice. (2) A second possible change-namely, the establishmont of the whole-time professors of clinical practice, though in principle only an expansion of the firsthas not unnaturally aroused much criticism and some oppcsition, for it would radically change the status and prospects of the professors of clinical practice. Personally I am convinced that this reform will eventually be effected with advantage both to medicine as a whole and to medical education. The ideal of the whole-time professors of medicine and surgery who, like the professors of pathology, expend all their energies in teaching and working at their branches of medical science, and are continually in touch with the wards which form thoin laboratories, has often been carried into effect, especially in Germany, in spirit, though not in the rigid letter as to total restriction from private practice. The whole-time professor should be appointed when comparatively young (30 to 40) so that he has a prospect of at least twenty years' active work. He would be provided with a staff of competent assistante of the sono colibre as those mentioned above, and must bo paid on edoguate salory and given a retiring pension griduated on the duration of service. The professor would be responsible for the organization of his department, would teach, pursue, and inspire original research, and set a high scientific standard. The advantages of the whole-time system-namely, undisturbed contact with the hospital patients and students, opportunities for uninterrupted research, for keeping up with the literature, fcr organizing a school of research workers, and the improvement in the teaching, both ordinary and advanced-which would thus result are sufficiently obrious. Much has been said on the other side; it lias been stated, among others by Sir William Osler, that it would be impossible to keep the pnblic away from a man so conspicuously and favourably placed; and that if this isolation could be preserved the professor would suffer from his narrowed outlook on medicine, or, as it has bcen expressed, that he would be a p:ofcssor" of hospital practice" rather than of "clinical medicine," and that he would come to regard patients somewhat in the same light as guinea-pigs and from the

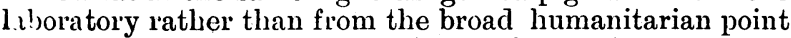
of vicw. (3) To debar the professors from private practice cuticely is as yet without precedeut in this country, and would necessitate very considerable financial cndowment. $\Lambda$ less radical change should be half or three-quarter time, and that one day and some afternoons in the week should ba free for practice; or that paying wards attached to the hospital should be at the professor's disposal, so as to minimize the waste of time involved in ordinary consulting practice. This would to some extent meet the financial difficulties and the objection that a whole-time appointment would cramp the professor. The drawback to any kind of part-time appointment is the difficulty in restricting the amount of private work, for though it might work well at first, the demands on such an incumbent's services must almost necessarily increase with time, and eventually encroach seriously on the professorial duties. (4) It is more satisfactory to combine research and the teaching and training of university students by whole-time professors and their skilled assistants than to make special arrangoments for original work alone, because the scientific spirit is thus more widely diffused. Instead of the establishment of whole-time professors in conditions favourable alike for research and scientific instruction, endowment has already been provided for scholarships, and in a few instances for research hospitals. It has becn urged at intervals since 1869 that there should be a one portal qualifying examination, corresponding to the State examination of other countries, so as to protect the public by ensuring a uniform standard of professional efficiency. As a result of the establish. mont of a one-portal system university degrees would bəcome honorary instead of qualifying, and, incidentally, eximining bodies which now grant ordinary diplomas to prastise would die of inanition. For the university degree some further requirements in the way of an examination (not a repetition of that carried out by the State board) would be necessary.

In order to make the medical degrees of nniversitics mean more than supcrior qualifications, alterations in, or rather additions to, the curriculum, such as one of the following, might be made: (1) Six or twelve montlis' residence as a medical oficer in a hospital might b3 demanded before the degree is conferred. In existing circumstances this would entail a qualification to practise from some licensing body, and would therefore add to the trials of the already over-burdened student. (2) Instead of the M.B. degree being the natural outcome of passing the necessary examinations, a thesis might be demanded so as to show how far the mind has been trained rather than crammed, and to bring out evidence of the ability to think and report logically and intelligently on what has been observed. (3) The students might pass for a period of twelve months or so into the hands of the whole.time professors of medicine, surgery, and obstetrics and gynaecology. There are, however, difieulties in the way of adopting a one-portal system of qualification. In the first place, the universities would have to give up their right to qualify their graduates to practise, an act of selfsacrifice which might not appear to them to be fully counterbalanced by the adrantages secured. The examina. tion, in oxder to be uniform, must be condneted by one board of examiners, which would be made up of represientatives of the various teaching universities in England, just as now holds goed to a certain extent in the constitution of the Conjoint Examining Board in England. It is doubtful if the provincial universities would consent to the examination being conducted exclusively in London; on account of the inconvenience both to their students and their representatives on the examining board. The written examination could be held in various centres, but if the clinical part were also decentralized it would be difficult to utilize the same examining board as in London, and if any extensive change in the personnel of the board occurred, the result might not be materially different from that at the present time.

\section{Introùntory Adudress}

\section{THE PRESENT DETY OF THE MEDICAI CITIZEN.}

Delivered on the Occasion of the Opening of the Winter Session at St. George's Hospital Medical SCHOOL.

\section{HAROLD GRIMSDALE, B.A., M.B.CANTab.,} F.R.C.S.,

OPHTHALMIC SCRGEON, ST. GEORGE'S HOSPITAL.

\section{(Abstract.)}

[Is the course of an address to students of St. Georgc's Hospital on October 1st, Mr. Grimsdale made the following observations:

It is reported that the great Abernethy on some occasion similar to the present greeted the newcomers as follows: "Good God, gentlemen, what is to become of you all?" His exclamation showed that even one hundred years ago the medical profession, in the opinion of one of its leaders, was over-full and not over-paid.

But if Abernethy werc herc now he would probably repeat his warning in even stronger terms. For in the present conditions, though he must admire your courage, he would doubt the worldly wisdom-I had almost said the sanity-of any man choosing the profession of medicine.

Abernethy was playing the part of a cynic ; and it may seem to you that there is ample justification for cynicism now; when the horizon of our outlook is hidden by clouds; and when it seems that medicine-never a lavish paymistress-may be unable to pay her followers what the phrase of the day calls a living wage. 
You, the newcomers, are entering the profession at a moment when it is engaged in a struggle for life. The course of study is more difficult and prolonged, the methods of examination necessary to successful diagnosis and treatment are more laborious and costly, and the competition keener than ever before. Modern methods have advanced so far that it is not possible for the general practitioner-however energetic, however capable-to carry out for himself all the investigations needful for diagnosis in certiain cases; and medicine is, at last, we hope, becoming a science as well as an art.

At this moment of critical development a blow has been aimed against advancing medicine, which, if it strikes, may well throw back our profession into the dark ages of the early part of the last century ; and the injury comes from the one authority which in a civilized State might be expected to understand the importance of modern medicine to the community-namely, the Government.

It has been a strange spectacle which has been presonted to the world during the months that have passed since the passage of the Insurance Act--a spectacle without parallel in the history of medicine. The profession must have been sorely tried before it rose almost unanimously in protest against such an Act.

It is not our own interest mainly that is impelling us to this unprecedented course; if it were, I am proud to think that fer medical men would have supported it; but we know that not only we, but through us the whole future of medicine and our present patients will suffer.

First let me say that there is not, and will not be, so far as any one can tell, a strike of medical men. We are told almost daily by one section of the press that we are employing the worst methods of trades unions; that we have adopted all the vices of syndicalism, and none of the virtues, if it has any ; that we have forfeited the right to the name of a generous profession.

We are certainly not on strike; for what is a strike? When the coal-miners struck, coal went up to such prices that the poor were unable to buy it at all, and the rich were forced to economize; when the taxi-drivers came out, taxis could hardly be procured; but there is no evidence that any medical man has refused to treat any sick person.

What is it, then. that has united the profession as it has never been united before? Why are all medical men throughout the country breaking away from all their natural instincts, unwilling to take service under the Act?

[The speaker then gave a history of the origin of club practice, of its progress up to the present, and an accoun of the evils created by it. He then continued as follows:

At the time when the Insurance Bill was first heard of, it was recognized by all that some system of State in surance against sickncss was most desirable. Medical men were all in favour of the idea. A workable scheme, providing a service throughout the country had indeed been suggested by some of them and had been tried in certain localities; medical men, therefore, taking into consideration that they would have to be the chief-workers under the Act, and that they had already some little experience in the treatment of the people who would come under it, remembering also that they had protested on every opportunity against the system of contract practice, not unreasonably expected that they would be asked through their organizations to advise on the best methods of working. However, as I shall tell you, they were not consulted; they might have thought, since they were going to bear all the risk, that the State would deal not. only fairly but generously with them.

They were doomed to disappointment. The action of the Government is barely credible and not at all creditablè.

The bill was brought in in May, 1911; in spite of repeated requests the Chancellor of the Exchequer saw the representatives of the British Medical Association for the first time in April. This was the only deputation from the Association received before the introduction of the bill, and at this meeting no special opportunity was afforded to the Association for ascertaining the provisions of the bill.

Nor, appavently, was the General Medical Council, nor the Royal Colleges of Physicians and Surgeons, treated with more courtesy. Presumably, the Chancellor had medical advisers; who they were has not. I think, been made known, but they certainly were not the assaciaticns of medical men who wonld have commanded the respect and been in some sense at least the representatives of medicine.

When the medical provisions were known, it was at once seen that they were most unfavourable to the best interests of medicine. In the first place, the payment was to be per caput; this alone must stamp any scheme as liable to failure. It is not in the interest of any man's work that he should be paid at a higher rate the less work he does. It cannot induce to keenness and initiative if the keen man is penalized because of his - keenness.

The more care taken in diagnosis and investigation tho less the reward. It nust not be forgotten that investigation on modern lines costs money, and this had to come out of the funds for payment of medical men.

The Chancellor of the Exchequer has throughout shown himself ignorant of the first requirements of modern medicine. It is, if one may judge from his attitude, his opinion that doctors are engaged in a guessing competition, with numbered bottles which agree with the number of the disease from which the patient suffers.

The difficulties of diagnosis, the prolonged examinations which are required to disentangle the symptoms, the intricate reactions-all these are nothing to him. His attitude is like the fabled sea captain, at sea with a sick seaman : looking up his handbook, he found that for the relief of the symptoms a dose should be given from a certain bottle numbered 15 in the ship's medicine chest. He turned to the chest and found the bottle empty. "What did you do ?" said a friend. "Well, first I gave him half a dose of 30 , and as that did no good I tried three doses of 5 , and he died." It is good as arithmetic, but it is not scientific medicine.

Then the medical men who form the panel are entircly under the power of the local Health Committee, which, though not the approved societies, will be made up chiefly of members of these societies; it has been repeatedly shown that lay control is not in the best interests of medicine.

Lastly, the suggested remuneration is inadequate; of course, it is perfectly true that nowhere is it laid down in the Act what the rate of remuneration is to be; but it is acknowledged that only a certain rate is justified by the actuaries. The Chancellor has been very generous-at our expense- to the working man in an approved society. Under the present Act the labouring man pays about $\frac{3}{4} \mathrm{~d}$. a week for his medical attention. He is often willing to pay 7s. 6d. a year for the fun of keeping a dog; it is not too much to expect that he should pay as much for kecping his health.

And, again, let me mentiun the case of firms who own large numbers of horses; they usually pay the veterinary surgeon a contract fee to look after them, and this is usually 21s. a head. Now, a horse cannot malinger and cannot demand unnecessary medical attention. Or we may look at this matter another way. The Government has been hitherto willing to pay $8 \mathrm{~s}$. $6 \mathrm{~d}$. a year for the medical attention of each employée in the Post Office, who are men of picked physique and in good health. It is not likely that the Government have been paying to the medical men who have had charge of these and other public servants twice the value of the services rendered. Why should we be asked now to undertake the treatment of all lives - healthy and unhealthy alike-who are com pelled by the Act to insure themselves at about half the sum which the Government has previously thought equitable for healthy lives?

And with this threatened increase in the scope of contract work tho value of the practice as a marketable asset has fallen, even more than Consols have done under the same master of finance.

Whatever the merits or demerits of the sale of practices, the fact that the goodwill has a market value and depends on the work of the holder of the practice must be taken into account in any scheme; now the present scheme has almost destroyed the valne in many instances. To give a'concrete example, an old St. George's man told me that about three years ago he contemplated selling the practice which he had built up entirely by himself; the best offer was $£ 1,000$, which for private reasons he did not accept. When the bill came in he again made inquiries, but his 
practice was virtually unsaleable; he did not get any offer over $£ 300$; thus the Chancellor had caused to him a loss of capital equal to $£ 700$.

In the days when I was studying medicine at Cambridge, a small book appeared which was entitled Fables, by George Washington Asop. From time to time I bought copies, but they were always borrowed by amused friends, and my last copy disappeared some time ago. The following quotation, therefore, is not literal, for, though I might have verified the words by dint of search in the library of the British Museum, I could not have improved on the sense which is contained in the following passage:

A kind-hearted She-Elephant, who was absent-mindedly wandering through the Jungle where the Spicy Breezes blow o'er Java' Isle, Heedlessly set foot on a Partridge, which she crushed to death, within a few inches of her Nest, filled by her Callow Brood. "Poor little things," said the warm-hearted Pachyderm, "My Carelessness has robbed them of their Natural Protector, but for the future my Sollicitude shall replace the Tender Ministrations they have lost." So saying she sat down on the Orphan Birds.

Very similar has been the action of the Government; the lumbering elephant, dreaming, it may be, of the rare and refreshing fruit in the distance, by its clumsy act has destroyed the value of the doctor's practice and robbed him of his freedom; and when this was pointed out, declared that it would make up all his losses by allotting the sum of $6 \mathrm{~s}$. per head; out of which, first the drugs and surgical appliances were to be paid for, and the balance, if there were any, was to be given for the doctor's services.

There is, however, one important respect in which the analogue does not hold good; the fabulist tells us-and he is the only person who can speak-that the she-elephant was moved to her mistaken action by sincere and wellmeaning pity. But does any medical man believe in the professions of the Gcvernment, of their interest in his welfare? There may be such an one, but I have yet to meet him. In the present negotiations the Government has been extraordinarily tender to the feelings of people of all kinds; in deference to the friendly societies they have given insurance only to those who join an approved society ; the leaflets by the Commissioners state that the deposit contributor, that is, the man who is compelled to enter the State scheme and cannot or will not join an approved society - is not really insured. The Government gives him no benefit beyond the amount standing to his individual account.

They have been very generous-at the expense of the medical profession - to the working man, who is probably earning more than the young doctor; they are even generous to the unqualitied practitioner, because they allow any insured person to employ any quack Christian Scientist or other charlatan, and his payment is as secure under the Act as that of any qualified man.

What, then, are the present duties of the medical man? It is, of course, the duty of every citizen to obey the law, so long as it is law; is it, then, our duty to accept the present Act and work under it? If by refusal to work we fail in our duty to our patients, we shall be breaking our Hippocratic tradition, and this we, as medical men, consider to be the primary and fundamental law governing our conduct. But no patient need suffer or is likely to suffer by our refusal. We shall not deny to the suffering poor those services which have been freely given in the past, but we shall demand from those who can afford it a reward not absolutely inadequate to the value of our service.

On the other hand, if we accept the present terms, we caunot carry out our duty towards our patient; we deliberately refuse him the advantage of progressive medicine, by binding ourselves to an old-I might almost say a fossil-krowledge.

Future gencrations will suffer for our want of independence to-day. Surely, then, we are fully justified in our rejection of the scheme designed by the Government, and in our determination to build up a better public medical service by our own efforts.

But we must have lofty thoughts, hold lofty ideals; then we need have no fear for the future, and may know that medicine will advance in spite of all discouragement though in our eagerness we experience small reverses, small mistakes.

That low man goes on adding one to one

His hundred's soon hit

This high man, aiming at a million, Misses an unit

Others mistrust and say, "But time escapes; Live now or never."

He said: "What's time? Leave Now for dogs or apes, Man has Forever."

\section{OPENING CEREMONIES AT THE MEDICAL SCHOOLS.}

THIS week the doors of practically all medical schools and faculties in London, the provinces, and Ireland have been reopened for the winter session, but not all on the same day. At many the date chosen was insufficiently early in the week for a record to appear in the present issue of any opening ceremonies which has marked the beginning thereat of another annus medicus. The special feature of the year, if any, has been a further move towards final extinction of the custom of selecting some one to give a formal address to the assembled students and their friends. This year there have been only one or two deliverances of that order. On the other liand, the practice of utilizing the opening day of the winter session as an occasion for a distribution of prizes in place of some more or less convenient day towards the end of the summer session seems to be growing in favour. In respect of annual gatherings of old students around the dinner table, there is no change whatever. An account of some of these meetings and other allied events here follows.

\section{ST. BARTHOLOMEW'S HOSPITAL.}

At St. Bartholomew's, one of the earliest medical schools to abandon the practice of opening the winter session witl a formal address, the customary gathering of old students at dinner took place on October 1 st. The dinner was held, as usual, in the Great Hall, which, however, this year presented a somewhat different appearance owing to the fact that the tables were disposed down the length of the room instead of across it. The plan has the advantage of allowing the noble proportions of this ancient hall to be better observed, but seems to have been adopted mainly in view of the increasing calls upon the space arising from the popularity of this annual gathering. This year the chairman was Dr. Lewis Jones, who has recently resigned charge of the electrical department. It is one which, as was pointed out by Sir ANTHONY BowLBY in proposing a toast in his honour, he practically created some twenty years ago and has conducted in such fashion as greatly to contribute to the placing of electro-therapeutics on a thoroughly sound and progressive footing. The toast to "St. Bartholomew's and its School" was proposed by Dr. Lewis Jones from the chair in a speech delivered with characteristic restraint of language. In its course he alluded to Sir Henry Butlin, whose death was a loss to surgery and to most of those present a personal loss in addition. Among changes in the staff which he mentioned was the retirement of Dr. Norman Moore from the post of Senior Physician. There could be no one present who had not enjoyed his learning and his talent for combining entertainment with instruction. He had been appointed Emeritus Lecturer on Medicine. On the surgical side Mr. Lockwood had retired from the teaching staff; in him would be missed an original-a fearless independent, whose teachings must have bitten indelibly into the memories of all who had had the advantage of listening to him. The school had to congratulate Sir Francis Champneys on becoming President of the Royal Society of Medicine, and Dr. Herringham, on his election as ViceChancellor of the University of London. Three colleges at Cambridge were now headed by St. Bartholomew's men-Downing by Professor Howard Marsh, Christ's College by Dr. Shipley, Gonville and Caius by Dr. Ander son. Good progress was being made in the movement towards obtaining a charter of incorporation of the school The latter provided the same instruction as the medical faculty of a university, but in present circumstances was solely dependent on the fees of students. As a corporate body with endowments to maintain lectureships it would bo 